\title{
A NEW SPECIES OF CYCLOPOGON (ORCHIDACEAE, SPIRANTHOIDEAE) FROM COLOMBIA
}

\author{
Dariusz L. SzlachetKo \& Marta Kolanowska ${ }^{1}$
}

\begin{abstract}
Cyclopogon antioquiensis Szlach. \& Kolan., a new species from Colombia, is described and illustrated. The differences between $C$. antioquiensis and similar species are briefly discussed and a key to the species of Cyclopogon subg. Cyclopogon is given. Information about the ecology and distribution of the new species is provided.
\end{abstract}

Key words: Cyclopogoninae, taxonomy, biodiversity, Antioquia, Neotropics

Dariusz L. Szlachetko \& Marta Kolanowska, Department of Plant Taxonomy and Nature Conservation, University of Gdańsk, Wita Stwosza 59,80-308 Gdańsk, Poland; e-mail: martakolanowska@wp.pl

\section{INTRODUCTION}

Cyclopogon C. Presl embraces 68-82 species distributed from Argentina to Florida (Salazar 2003; Rutkowski et al. 2008). The only exception to the Neotropical representatives of the genus is C. obliquus (J. J. Sm.) Szlach., having a disjunctive geographical range. This orchid was described based on Asian material and has also been reported from the Caribbean and Central America south to Costa Rica (Blanco 2002). Ortiz Valdivieso and Uribe Vélez (2007) listed 12 species of Cyclopogon occurring in Colombia. Five of them were found in Antioquia Department where they grow above $1500 \mathrm{~m}$ a.s.l. (Idárraga \& Callejas 2011).

The genus Cyclopogon was described by Carl Presl in 1827 without selecting the generic type, which was designated by Garay (1978) as C. ovalifolium C. Presl. Based on morphological characters, Dressler (1993) classified the genus within subtribe Spiranthinae Lindl. Two years later, Szlachetko (1995) proposed a reconsideration of the spiranthoid orchids with a description of a new subtribe, Cyclopogoninae, which included Cyclopogon Presl and Pelexia Lindl. and others. Data from molecular studies (Chase et al. 2003) suggested a wide concept of Spiranthinae, placing

\footnotetext{
1 Corresponding author
}

here also representatives of Stenorrhynchidinae and Cyclopogoninae sensu Szlachetko (1995). In this approach, however, synapomorphies (e.g., adhesion of the lip margins to the gynostemium sides) are observed (Salazar et al. 2003).

Despite the controversial taxonomical position of the genus, its representatives are easily distinguished from the other spiranthoid orchids by the petiolate leaves forming a basal rosette, pubescent inflorescence, resupinate, tubular, externally pubescent flowers with a shortly clawed, bipartite lip adnate to the lateral sepals and margins adherent to the sides of the gynostemium forming a tunnellike access to the nectary. The gynostemium of Cyclopogon is rather slender and erect, with the column part as long as or shorter than the anther. The column-foot is short and obliquely adnate to the ovary apex. The anther is erect, motile, dorsiventrally flattened and 2-chambered. The pollinia are powdery with a short caudiculae in the apical parts. The ventral, bilobed stigma is flat, and the membranous, linear-lanceolate rostellum is erect or curved upwards. The single, detachable, obovoid to ovoid viscidium is produced on the upper surface of the rostellum (Szlachetko \& Rutkowski 2000).

Cyclopogon species grow in moist to wet montane and cloud forest, ravines, riparian vegetation 
in tropical deciduous and semi-deciduous forests, shrubby savannas and grasslands, and also in rocky fields and bogs. They have been reported growing from sea level up to $c a 3000 \mathrm{~m}$ a.s.1. (Salazar 2003). The halictid bees were reported as pollinators of Brazilian species, but Bombus spp. and Apis spp. were also observed visiting Cyclopogon flowers. Some representatives probably are selfpollinating (Catling 1990).

Our revision of the orchid material stored in the Colombian National Herbarium (COL) revealed the existence of a distinctive Cyclopogon species, described here as new. The perianth segment characteristics are based on our examination of three flowers.

\section{DESCRIPTION OF THE NEW SPECIES}

Cyclopogon antioquiensis Szlach. \& Kolan., sp. nov. Fig. 1

The species is distinguished from all other members of Cyclopogon subgenus Cyclopogon described so far by its shortly clawed lip, lip auricles ornamented by horn-like projections, and petals prominently constricted below the apex.

Holotype: COLOMBIA, Antioquia, Mpio. Urrao. Corregimiento La Encarnacion. Vereda Calles, Parque Nacional Natural Las Orquideas, frente a la cabana de Calles. $6^{\circ} 31^{\prime} 9.1^{\prime \prime} \mathrm{N} 76^{\circ} 15^{\prime} 8.4^{\prime \prime} \mathrm{W}$. Vegetacion secundaria a la orilla del rio Calles, Alt. 1357 m, 25 Jan. 2011, Betancur et al. 14624 (COL).

Plants ca $30 \mathrm{~cm}$ tall. Leaves 7, basal, rosulate; petiole up to $6.5 \mathrm{~cm}$ long, narrow; blade up to $7.5 \mathrm{~cm}$ long and $3.2 \mathrm{~cm}$ wide, ovate-lanceolate, acute. Peduncle erect, slender, glandular in the upper half, covered by 13 herbaceous, acute, lanceolate sheaths. Rachis $6 \mathrm{~cm}$ long, densely many-flowered. Flowers small, tubular, glabrous. Floral bracts $13 \mathrm{~mm}$ long, lanceolate, acute, herbaceous. Subsessile ovary $8-10 \mathrm{~mm}$ long. Dorsal sepal $7.5 \mathrm{~mm}$ long, $1 \mathrm{~mm}$ wide, oblong-obovate, abruptly narrowed towards blunt apex, concave above middle, 3-nerved. Petals $7 \mathrm{~mm}$ long, $0.6 \mathrm{~mm}$ wide, subfalcate, oblanceolate above linear base, constricted in apical 1/6-1/5, apical part subquadrate, truncate, 1-nerved. Lateral sepals $9 \mathrm{~mm}$ long,
$0.9 \mathrm{~mm}$ wide, connate together in lower half, oblong-ligulate, somewhat oblique at apex, subobtuse, 1-nerved. Lip $9 \mathrm{~mm}$ long, shortly clawed; hypochile and isthmus $7 \mathrm{~mm}$ long, $2 \mathrm{~mm}$ wide at broadest point, oblong, with two wing-like lobes near middle, covered by glandular hairs in center;
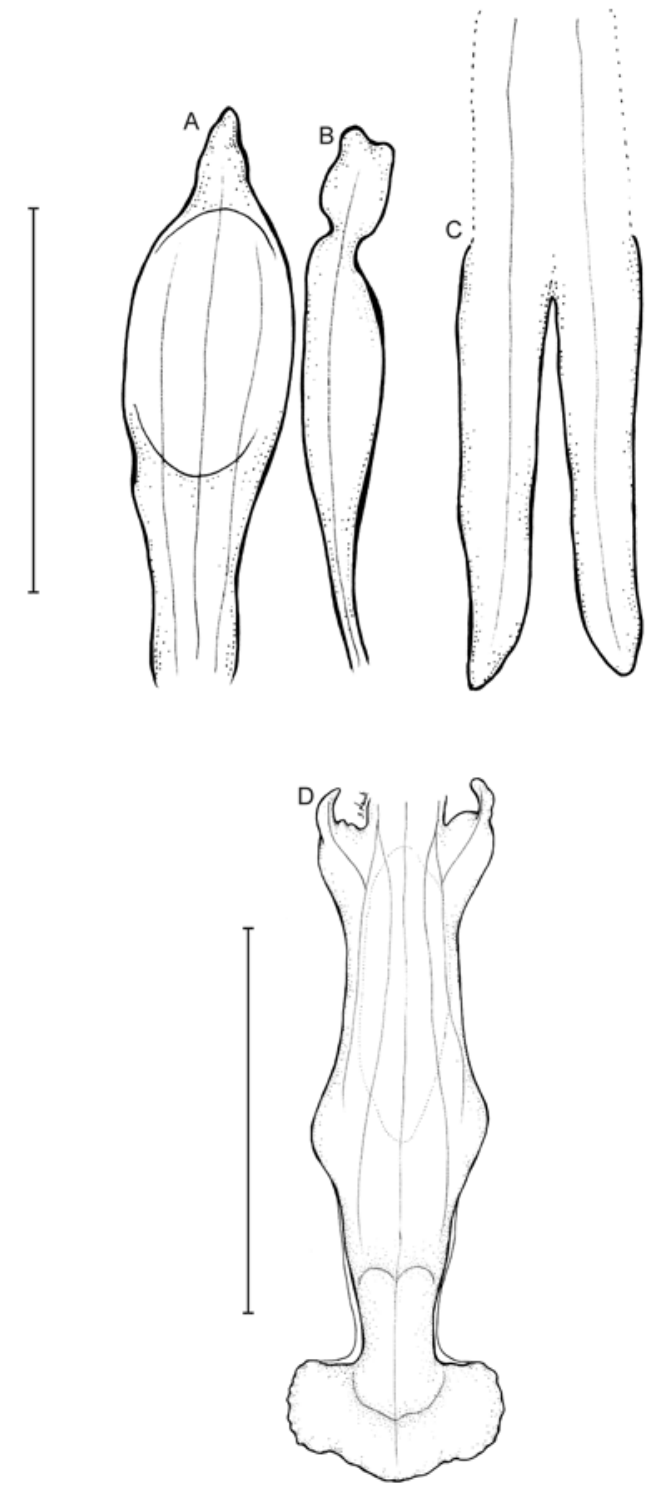

Fig. 1. Cyclopogon antioquiensis Szlach. \& Kolan. sp. nov. - dissected perianth. A - dorsal sepal, B - petal, C - lateral sepals, D - lip (drawn by S. Nowak from the holotype). Scale bars $=5 \mathrm{~mm}$. 
Table 1. Comparative morphology of Cyclopogon antioquiensis Szlach. \& Kolan. sp. nov., C. ovalifolium C. Presl and C. secundum E. A. Christenson.

\begin{tabular}{|c|c|c|c|}
\hline Character & C. antioquiensis & C. ovalifolium & C. secundum \\
\hline Leaf blade & Ovate-lanceolate, acute & $\begin{array}{l}\text { Obliquely elliptic to ovate- } \\
\text { elliptic, acute }\end{array}$ & Elliptic, attenuate, subacute \\
\hline Inflorescence & $\begin{array}{l}\text { Densely flowered, secund; } \\
\text { peduncle covered with many } \\
\text { lanceolate sheaths }\end{array}$ & $\begin{array}{l}\text { Subdensely flowered, secund; } \\
\text { peduncle covered with several } \\
\text { lanceolate sheaths }\end{array}$ & $\begin{array}{l}\text { Densely flowered, secund; } \\
\text { peduncle covered with several } \\
\text { lanceolate sheaths }\end{array}$ \\
\hline Floral bracts & Lanceolate, about $13 \mathrm{~mm}$ long & $\begin{array}{l}\text { Linear to linear-setaceous, up to } \\
15 \mathrm{~mm} \text { long }\end{array}$ & $\begin{array}{l}\text { Narrowly linear-lanceolate, } \\
\text { aciculate, up to } 13 \mathrm{~mm} \text { long }\end{array}$ \\
\hline Sepals & $\begin{array}{l}\text { Oblong-obovate to oblong- } \\
\text { ligulate, subobtuse }\end{array}$ & Linear-ligulate, obtuse & Oblong, obtuse \\
\hline Petals & $\begin{array}{l}\text { Oblanceolate above the linear } \\
\text { base, truncate }\end{array}$ & Linear-subspathulate, rounded & Oblong, obtuse \\
\hline Sepaline tube & $4.5 \mathrm{~mm}$ long & $2.5-3.5 \mathrm{~mm}$ long & $3 \mathrm{~mm}$ long \\
\hline Lip - basal auricles & $\begin{array}{l}\text { Ornamented by horn-like } \\
\text { projection }\end{array}$ & Rounded, flat, truncate & Rounded, retrorse \\
\hline Lip - hypochile & $\begin{array}{l}\text { Oblong, covered by glandular } \\
\text { hairs in the center; up to } 2 \mathrm{~mm} \\
\text { wide }\end{array}$ & $\begin{array}{l}\text { Linear-oblong, covered by } \\
\text { glandular hairs in the center; up } \\
\text { to } 3 \mathrm{~mm} \text { wide }\end{array}$ & $\begin{array}{l}\text { Oblong, covered by glandular } \\
\text { hairs in the center; up to } 3 \mathrm{~mm} \\
\text { wide }\end{array}$ \\
\hline Lip - epichile & $\begin{array}{l}\text { transversely elliptic, obscurely } \\
\text { 3-lobed at the apex, thickened } \\
\text { and papillate at the base }\end{array}$ & Transversely elliptic, papillate & $\begin{array}{l}\text { Transversely elliptic, obscurely } \\
\text { lobulate, densely pubescent at } \\
\text { the central part }\end{array}$ \\
\hline
\end{tabular}

epichile $1.5 \mathrm{~mm}$ long, $3 \mathrm{~mm}$ wide, transversely elliptic, obscurely 3-lobed at apex, thickened and papillate at base. Gynostemium $6 \mathrm{~mm}$ long. Capsule not seen.

ETYMOLOGY. In reference to the place of origin of the type specimen.

Distribution AND eCOlogy. Cyclopogon antioquiensis is known so far from the Western Cordillera in Antioquia Department, Colombia. It grows at $c a 1350 \mathrm{~m}$ a.s.l. Flowering in January. As it is known from a single specimen, its conservation status cannot be given. Because the flowers of Cyclopogon are not showy or attractive to horticulturists and the plants are difficult to maintain in culture, the direct risk to wild plants from collectors is not significant.

NotEs. There are three species of Cyclopogon subg. Cyclopogon described so far: C. ovalifolium C. Presl, widely distributed in the Andes, C. secundum E. A. Christenson from Ecuador, and the above-described $C$. antioquiensis. All of them are characterized by the presence of the sepaline tube; that character separates it clearly from the subgenus Beadlea (Small) Szlach. The morphological characters of the three species are compared in Table 1.

\section{KeY TO THE SPECIES}

OF CYCLOPOGON SUBG. CYCLOPOGON

1. Lip epichile densely pubescent ............. $\ldots \ldots \ldots$. . . secundum E. A. Christenson 1. Lip epichile papillate, never pubescent ...... 2

2. Basal lip auricles truncate $\ldots \ldots \ldots \ldots \ldots \ldots$ $\ldots \ldots \ldots \ldots \ldots$ C. ovalifolium C. Presl

2. Basal lip auricles ornamented by horn-like projection ...... C. antioquiensis Szlach. \& Kolan.

ACKNOWLEDGEMENTs. The curator and staff of herbarium COL are thanked for their kind hospitality and assistance during visits, and for making specimens available on loan. We are grateful to Professor Tarciso Filgueiras and the anonymous reviewer for helpful remarks on the manuscript, and to Sławomir Nowak for preparing the illustration. The research described here was supported by the Polish Ministry of Science and Higher Education (research grant no. 8124/B/PO1/2011/40). 


\section{REFERENCES}

Blanco M. A. 2002. Notes on the natural history of Cyclopogon obliquus (Orchidaceae: Spiranthinae) in Costa Rica. Lankesteriana 5: 3-8.

Catling P. M. 1990. Biology of the North American representatives of the Subfamily Spiranthoideae. In: C. E. SAWYERS (ed.), North American native terrestrial orchid propagation and production. Brandywine conservancy, pp. 46-67. Chadds Ford, Pennsylvania.

Chase M. W., Freudenstein J. V., Cameron K. M. \& BarRETT R. L. 2003. DNA data and Orchidaceae systematics: a new phylogenetic classification. In: K. W. Dixon, S. P. Kell, R. L. Barrett \& P. J. CribB (eds.), Orchid conservation, pp. 69-89. Natural History Publications, Kota Kinabalu, Borneo.

Dressler R. L. 1993. Phylogeny and classification of the orchid family. Dioscorides Press, Portland.

Garay L. A. 1978. Orchidaceae, Cypripedioideae, Orchidoideae, Neottioideae. In: G. Harling \& B. Sparre (eds), Flora of Ecuador. 9: 258. Department of Systematic Botany, University of Göteborg and the Section for Botany, Riksmuseum, Stockholm.

IDÁrraga P. A. \& Callejas P. R. 2011. Análisis florístico de la vegetación del Departamento de Antioquia. In: A. IDÁRraga, R. Del C. Ortiz, R. Callejas \& M. Merello (eds), Flora de Antioquia: catálogo de las plantas vasculares. 2. Listado de las plantas vasculares del departamento de Antioquia, pp. 667-668. Programa Expedición Antioquia-
2103. Series Biodiversidad y Recursos Naturales. Universidad de Antioquia, Missouri Botanical Garden \& Oficina de planeación departamental de la gobernación de Antioquia, Editorial D’Vinni, Bogotá, Colombia.

Ortiz Valdivieso P. \& Uribe Vélez C. 2007. Galería de orquídeas de Colombia. (CD edition). Asociación Bogotana de Orquideología, Bogotá.

Presl C. B. 1827. Orchidaceae. Reliq. Haenk. 1(2): 93, pl. 13.

Rutkowski P., Szlachetko D. L. \& Górniak M. 2008. Phylogeny and taxonomy of the subtribes Spiranthinae, Stenorrhynchidinae and Cyclopogoninae (Spirantheae, Orchidaceae) in Central and South America. Wydawnictwo Uniwersytetu Gdańskiego, Gdańsk.

Salazar G. A. 2003. Cyclopogon. In: A. Pridgeon, P. J. CribB, M. W. Chase \& F. Rasmussen (eds), Genera Orchidacearum, 3: Orchidoideae part 2, Vanilloideae, pp. 188-192. Oxford University Press, Oxford.

Salazar G. A., Chase M. W., Soto Arenas M. A. \& INGROUILLE M. 2003. Phylogenetics of Cranichideae with emphasis on Spiranthinae (Orchidaceae, Orchidoideae): evidence from plastid and nuclear DNA sequences. Amer. J. Bot. 90: 777-795.

SzlachetKo D. L. 1995. Systema orchidalium. Fragm. Florist. Geobot., Suppl. 3: 1-152.

Szlachetko D. L. \& Rutkowski P. 2000. Gynostemia Orchidalium. 1. Apostasiaceae, Cypripediaceae, Orchidaceae (Thelymitroideae to Vanilloideae). Acta Bot. Fenn. 169: 279 .

Received 30 June 2013 